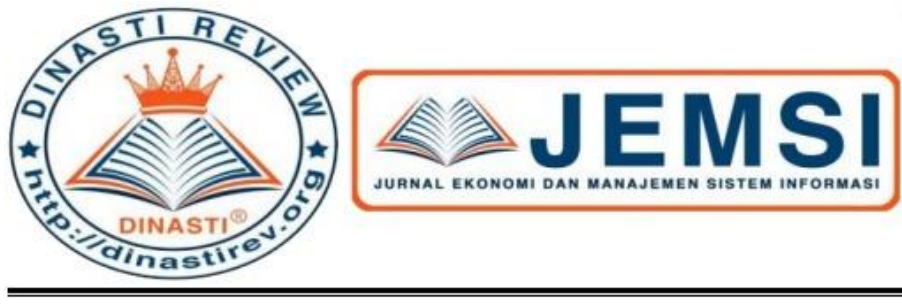

$+62878-9658-6407$ 087896586407 ()

https://dinastirev.org/JEMSI (-) editor@dinastirev.org (G.

\title{
PENERAPAN 7P SEBAGAI STRATEGI PEMASARAN PENDIDIKAN TINGGI
}

\author{
Maisah $^{1)}$, Mahdayeni $^{2}$, Maryam $^{3)}$, Muhammad Roihan Alhaddad ${ }^{4)}$ \\ 1) UIN Sulthan Thaha Saifuddin, Jambi, Indonesia \\ 2,3) IAI Nusantara Batanghari, Muara Bulian, Indonesia \\ 4) STIT Raudhatul Ulum, Palembang, Indonesia
}

\begin{tabular}{|c|l|}
\hline $\begin{array}{c}\text { ARTICLE INFORMATION } \\
\text { Received: 12 Maret 2020 } \\
\text { Revised: 17 Maret 2020 } \\
\text { Issued: 23 Maret 2020 }\end{array}$ & $\begin{array}{l}\text { Abstrak: Dalam pendekatan pemasaran jasa telah } \\
\text { dikembangkan sebuah alat terpenting, yaitu marketing } \\
\text { mix. Selanjutnya dalam marketing mix dikenal } \\
\text { dengan istilah 7P sebagai alat marketing paling tepat } \\
\text { sebagai pendekatan terhadap peserta didik, sebab } \\
\text { marketing mix klasik 4P tidak cukup efisien dalam } \\
\text { mendorong sebuah universitas atau perguruan tinggi. } \\
\text { Corresponding author: } \\
\text { Kaisah }\end{array}$ \\
promotion, people, physical, process
\end{tabular}

\section{PENDAHULUAN}

Indonesia sebagai salah satu negara di Asia terus mengalami perkembangan dan perubahan, tidak terkecuali di dunia pendidikan. Adanya reformasi dibidang pendidikan seperti privatisasi, internasionalisasi, desentralisasi, dan perubahan struktur pendidikan tinggi membawa pendidikan pada lingkungan yang kompetitif. Diterapkannya AFTA atau Asia Free Trade Asia pada tahun 2003-an membawa dampak semakin meningkatkan kebutuhan tinggi kualitas sumber daya manusia yang membawa setiap organisasi untuk saling bersaing untuk mendapatkan maupun menghasilkannya. Era globalisasi sekarang ini juga membawa dampak pada dunia pendidikan, khususnya pendidikan tinggi atau universitas untuk dikelola secara profesional bukan tradisional, sehingga berkompetisi menghasilkan output yang berkualitas dan dapat bersaing secara luas di kancah internasional.

Tuntutan kompetisi yang intensif dalam dunia pendidikan mendorong lembaga pendidikan tinggi untuk lebih berorientasi pada konsep pemasaran dan mengembangkannya sebagai sebuah strategi. Sebuah lembaga pendidikan tinggi apabila ingin meraih kesuksesan di masa depan dalam menghadapi bagaimana mendapatkan jumlah mahasiswa yang dikehendaki, haruslah mempraktekkan praktik marketing secara terintegrasi. Jumlah mahasiswa akan sangat berpengaruh pada finansial perguruan tinggi dan akan berpengaruh pula pada proses pembelajaran dalam rangka menghasilkan output yang berkualitas. Banyaknya jumlah mahasiswa juga akan memperkuat posisi dan nama baik sebuah lembaga pendidikan, karena akan semakin banyak jumlah dana yang masuk, dan mengeluarkan banyak alumni yang membawa efek kebaikan ganda. Dalam banyak literatur disebutkan pasar perguruan tinggi sekarang merupakan fenomena global. Untuk merespon perubahan ini, nilai-nilai, keefektifan dan manfaat potensial dari penggunaan teori dan konsep pemasaran yang secara efektif telah 
diterapkan dalam dunia bisnis, secara bertahap kini mulai diterapkan di perguruan tinggi/universitas, yang dimaksudkan untuk memenangkan persaingan dan mendapatkan ruang yang lebih besar dalam pasar internasional.

Marketing sesungguhnya bukanlah hal baru dalam lembaga pendidikan. Layaknya sebuah corporate, lembaga pendidikan menghasilkan jasa pendidikan yang akan dibeli oleh konsumennya, yaitu siswa/mahasiswa dan orang tua. Marketing dalam pendidikan tinggi tidaklah semata-mata hanya mengejar laba, tetapi fokus marketing pendidikan tinggi saat ini adalah berorientasi pada kepuasan konsumen, bahkan lebih jauh lagi tidak hanya menjadi konsumen tetapi targetnya bisa menjadi pelanggan lembaga pendidikan.

Dapat dipahami bahwa dalam melaksanakan transaksi jasa pendidikan juga dimaksudkan untuk memberikan kebahagiaan (keridhaan) pada pelanggan lembaga pendidikan sehingga mereka mendapatkan kepuasan. Semakin banyak uang yang dibayarkan, maka makin tinggi pula harapan dan semakin tinggi pula tingkat kepuasan yang ingin diraih. Inilah yang hendak dicapai oleh sebuah lembaga pendidikan.

Dalam pendekatan pemasaran jasa telah dikembangkan sebuah alat terpenting, yaitu marketing mix. Selanjutnya dalam marketing mix dikenal dengan istilah $7 \mathrm{P}$ sebagai alat marketing paling tepat sebagai pendekatan terhadap peserta didik, sebab marketing mix klasik 4P tidak cukup efisien dalam mendorong sebuah universitas atau perguruan tinggi.

Bauran pemasaran (marketing mix) jasa 7P turut membentuk image institusi pendidikan tinggi melalui kegiatan pemasaran seperti fasilitas fisik, kemampuan dan pengetahuan pendidik, kemudahan akses dan berita lewat internet serta simposium yang dilaksanakan oleh lembaga pendidikan tersebut. Ketika image baik telah terbentuk, impresi positif yang dihasilkan dapat meningkatkan kemungkinan institusi pendidikan tersebut untuk dipilih. Dalam penentuan pemilihan lembaga pendidikan terdapat faktor diluar personal yang meliputi kesan, impresi, perasaan atau konsepsi konsumen akan suatu lembaga pendidikan tersebut. Image atau reputasi akan institusi pendidikan tinggi memiliki pengaruh kuat dan memiliki daya persuasif yang tinggi terhadap pemilihan konsumen akan sebuah lembaga pendidikan tinggi. Reputasi dan kualitas lembaga pendidikan merupakan faktor yang paling berpengaruh dalam menarik mahasiswa untuk masuk ke universitas tertentu. Calon mahasiswa biasanya dalam memilih universitas melalui sebuah proses seleksi yang hati-hati. Dalam proses ini bauran pemasaran jasa 7P secara positif juga memiliki pengaruh terhadap mahasiswa dalam mengambil keputusan untuk memilih perguruan tinggi untuk tempat mereka belajar.

\section{Konsep Dasar Strategi Pemasaran}

Strategi secara etimologi, berasal dari bahasa Yunani "stratagos", yang berarti jendral atau komandan militer. Menurut Bittel, strategi adalah suatu rencana yang fundamental untuk mencapai tujuan perusahaan.(Buchari Alma, 2011) Sedangkan dalam KBBI, diartikan sebagai suatu rencana cermat mengenai kegiatan untuk mencapai sasaran khusus. (Anonim, 2005) Menurut John A. Byrne, strategi adalah sebagai sebuah pola yang mendasar dari sasaran yang berjalan dan yang direncanakan, penyebaran sumber daya dan interaksi organisasi dengan pasar, pesaing, dan faktor-faktor lingkungan.(Ali Hasan, 2010) Sedangkan menurut dua pakar strategi yaitu Hamel dan Prahalad, mereka menyebutkan bahwa strategi merupakan tindakan yang bersifat incremental (senantiasa meningkat) dan terus menerus serta dilakukan berdasarkan sudut pandang tentang apa yang diharapkan oleh parapelanggan di masa depan.(Husein Umar, 2010)

Adapun pengertian pemasaran dapat dilihat dari defenisi yang dirumuskan oleh The American Marketing Association berikut:

"Marketing is the planning and executting the conception, pricing, promotion and distribution of ideas, googs and services to create excanges that satisfiy individual and organizational goals" (Graham J, 2008)'

Defenisi di atas mengandung arti bahwa pemasaran adalah suatu proses perencanaan dan 
menjalankan konsep, harga, promosi dan distribusi sejumlah ide, barang, dan jasa untuk menciptakan pertukaran yang mampu memuaskan tujuan individu dan organisasi. Sedangkan menurut Chartered Institute of Marketing, menyebutkan bahwa pemasaran adalah: "Management process of antipating, identifying and satisfying customer requirements profitably". (Colin Gilligan, 2009).

Tersirat bahwa pemasaran adalah suatu proses manajemen yang bertanggung jawab untuk mengenali, mengantisipasi dan memuaskan keinginan atau kebutuhan pembeli demi meraih laba. Stanton dalam Swastha dan Irawan, mendefenisikan pemasaran adalah suatu sistem keseluruhan dari kegiatan-kegiatan bisnis yang ditujukan untuk merencanakanan, menentukan harga, mempromosikan, dan mendistribusikan barang dan jasa yang memuaskan kebutuhan baik kepada pembeli yang ada maupun pembeli potensial.(Basu Swastha, 2008) Kotler dan Keller mengartikan:

"Marketing is a societal process by which individuals and groups obtain what they need and want through creating, offering, and freely exchanging product and services of value with others".(Philip Kotler, 2012)

Konsep inti marketing (pemasaran) pada dasarnya menekankan pada "kepuasan konsumen". Tujuan marketing untuk memuaskan selera dan memenuhi "needs and wants" dari konsumen. Needs diartikan kebutuhan yang didefinisikan sebagai "rasa kekurangan pada diri seseorang yang harus dipenuhi". Sedangkan wants sebagai keinginan yang didefinisikan sebagai suatu kebutuhan yang sudah dipengaruhi oleh berbagai faktor, seperti daya beli, pendidikan, agama, keyakinan, keluarga dan sebagainya. Agar tujuan utama dalam proses marketing tersebut dapat tercapai, maka diperlukan strategi marketing yang baik,agar harapan dan keinginan konsumen dapat terpenuhi sesuai dengan pelayanan yang didapatkan. Hal ini menunjukkan bahwa, peran strategi marketing sangat penting dalam mewujudkan kepuasan konsumen, sebagai salahsatu indikator utama dalam konsep pemasaran.

Penerapan Strategi pemasaran dimaksudkan sebagai proses untuk mengembangkan, dan memelihara kesesuaian strategis antara tujuan dan kemampuan lembaga, serta perubahan peluang pemasaran. Strategi pemasaran meliputi aktivitas untuk mengembangkan misi yang jelas, mendukung tujuan dan sasaran lembaga, strategi yang logis, serta pelaksanaan yang tepat. Dibalik berhasilnya proses pemasaran, terdapat unsur-unsur yang mendukung berhasilnya suatu proses pemasaran. Ada tiga unsure utama yang terdapat dalam pemasaran, yaitu:

1. Segmentasi pasar, yaitu tindakan mengidentifikasi dan membentuk kelompok pembeli ataukonsumensecara terpisah,

2. Targetting, yaitu tindakan memilih satu atau lebih segmen pasar yang akan dimasuki.

3. Positioning yaitu penetapan posisi pasar dengan tujuan untuk membangun dan mengkomunikasikan keunggulan bersaing produk yang ada di pasar, ke dalam benak konsumen.

\section{Peran Strategi Marketing dalam Pendidikan}

Pendidikan dalam perspektif manajemen dapat dipahami sebagai proses pelayanan pengetahuan sehingga produk yang dihasilkan oleh lembaga pendidikan ialah jasa pelayanan ilmu pengetahuan. Sebagai penyedia jasa, lembaga pendidikan diharapkan dapat menghasilkan produk yang sesuai dengan kebutuhan dan permintaan pelanggan (masyarakat).Konsep strategi pemasaran (marketing strategy) untuk memprediksi permintaan dan kebutuhan masyarakat terhadap output lembaga pendidikan. Menurut Fandy Tjiptono, bahwa konsep pemasaran dalam pendidikan merupakan kegiatan memberi layanan jasa pendidikan, kepada konsumen dengan cara yang memuaskan.(Fandy Tiptono, 2014) Pendapat ini, menunjukkan pentingnya lembaga pendidikan untuk terus aktif dan kreatif dalam mengelola pendidikan agar produksi pengetahuan yang dihasilkan sesuai dengan tuntutan dan perkembangan zaman sebagaimana harapan masyarakat.

Pentingnya lembaga pendidikan menjaga kepuasan masyarakat, telah diungkapkan 
bahwa semakin mahal biaya pendidikan, maka para konsumen akan menuntut mutu pendidikan itu harus lebih baik dan berkualitas. Hal ini memberikan kesadaran yang mendasar, bahwa bukan persoalan tinggi-rendahnya biaya pendidikan yang menjadi masalah utama, namun justru kualitas dari lembaga pendidikan itulah yang lebih dipersoalkan. Melalui penerapan strategi pemasaran yang baik, diharapkan dapat menjaga keseimbangan biaya pendidikan dengan kualitas lembaga pendidikan itu sendiri. Hal ini penting untuk memberikan kepuasan kepada masyarakat selaku konsumen, dan sekaligus memberikan motivasi kepada lembaga pendidikan, untuk terus maju dan berkembang.

Menurut Kotler, jasa adalah " a service is any actor performance that one party can offer, to another that isessentially in tangible and does notresultin the ownership of anything. Its production may or may, not be tied to a physical product". Dengan demikian, jasa adalah setiap tindakan atau kinerja yang ditawarkan oleh satu pihak pada pihak yang lain, yang secara prinsip tidak berwujud, dan tidak menyebabkan kepindahan kepemilikan.(Yoyon, 2011) Kotler juga menambahkan empat karakteristik jasa, yaitu: (1) tidak berwujud, sehingga konsumen tidak dapat melihat, mencium, meraba, mendengar, dan merasakan hasilnya sebelum membelinya, (2) tidak terpisahkan (inseparability) dari sumbernya yaitu perusahaan jasa, (3) bervariasi (variabiliy), sering berubah- ubah tergantung siapa, kapan jasa disajikan, (4) mudah musnah (perishability), jasa tidak dapat dijual pada masa yang akan datang. (Yoyon, 2011)

Pentingnya pemasaran jasa pendidikan, menurut Wijaya untuk membantu madrasah dalam meningkatkan kepuasan pelanggan. Hal ini penting, untuk memenangkan kompetisi antar sekolah, serta meningkatkan akselerasi peningkatan kualitas dan profesionalisme manajemen lembaga.(David Wijaya, 2012) Penerapan strategi pemasaran dapat dilihat ketika penerimaan siswa baru selalu muncul iklan-iklan dari sekolah di surat kabar, radio, media cetak, dan spanduk di pinggir jalan. Semua ini bertujuan untuk menarik perhatian calon siswa sebagai pelanggan pendidikan.(Buchari Alma, 2008) Penerapan strategi pemasaran yang baik diharapkan persaingan lembaga pendidikan dapat melahirkan kultur kompetisi yang sehat dan dinamis.

\section{METODE PENELITIAN}

Metode penelitian yang digunakan dalam tulisan ini adalah metode deskriptif analitis, maksudnya menggambarkan atau melukiskan pendidikan Islam di Indonesia, dengan menilik sejarah masa kerajaan Islam di Indonesia. Adapun analisis yang digunakan adalah analisis kualitatif, yang tidak membutuhkan angka-angka.

\section{HASIL DAN PEMBAHASAN}

\section{Penerapan Strategi Pemasaran 7P di Lembaga Pendidikan Tinggi}

Unsur-unsur yang terdapat dalam pemasaran terdiri dari tujuh aspek utama. Empat aspek tradisonal berhubungan dengan pemasaran barang, dan tiga aspek selanjutnya berhubungan dengan perluasan pemasaran. Empat aspek tradisional, yaitu: product (produk), price (harga), place (lokasi/tempat), dan promotion (promosi). Adapun tiga aspek, perluasan pemasaran, ialah people (sumber daya manusia), physical evidence (bukti fisik), dan process (manajemen layanan yang diberikan). (Imam Machali, 2016) Adapun uraian teoritis mengenai ketujuh aspek tersebut, ialah sebagai berikut:

\section{Product (Produk) Jasa Perguruan Tinggi}

Produk diartikan sebagai sekumpulan atribut berupa fitur, fungsi, manfaat, dan penggunaan, yang digunakan untuk memberikan kepuasan kepada konsumen. Menurut Kotler, produk adalah segala sesuatu yang dapat ditawarkan ke pasar untuk memenuhi keinginan atau kebutuhan.(Kotler, 2012) Lebih spesifik lagi dijelaskan oleh Keegan, bahwa produk adalah:

"Koleksi sifat-sifat fisik, jasa, dan simbolik yang menghasilkan kepuasan, atau manfaat bagi seorang pengguna atau pembeli. Manajemen produk berkaitan dengan keputusan yang 
mempengaruhi persepsi pelanggan dari produk yang ditawarkan oleh perusahaan".(Buchari Alma, 2008)

Dari pengertian di atas dapat disimpulkan bahwa produk merupakan suatu kumpulan sifatsifat fisik, jasa dan simbolik yang menghasilkan kepuasan atau manfaat bagi seorang pengguna atau pembeli yang dapat ditawarkan ke pasar dan akan mempengaruhi persepsi pelanggan dalam melakukan pembelian. Dalam kerangka perilaku konsumen, produk merupakan salah satu indikator dalam melakukan pencarian, pembelian, penggunaan, dan evaluasi produk.(Hesty, 2018) Dalam strategi pemasaran, kualitas produk yang dihasilkan dan ditawarkan haruslah berkualitas, sebab konsumen tidak senang pada produk kurang bermutu, apalagi harganya mahal. Dalam bauran produk, hal yang ingin dicapai ialah diferensiasi produk, untuk memudahkan konsumen mengenali produk yang dipasarkan oleh produsen.

Dalam jasa pendidikan tinggi, produk/jasa yang ditawarkan kepada mahasiswa adalah reputasi, prospek, dan variasi pilihan. Perguruan Tinggi yang akan bertahan dan mampu memenangkan persaingan dengan PT lain, baik yang ada di dalam maupun di luar negeri adalah PT yang dapat menawarkan reputasi/mutu pendidikan yang baik, prospek yang cerah bagi mahasiswa setelah lulus dari PT tersebut, dan pilihan konsentrasi yang bervariasi sehingga calon mahasiswa bisa memilih bidang konsentrasi yang sesuai dengan bakat dan minang mereka. Contoh produk/jasa yang bisa ditawarkan oleh PT adalah:

1) Menyediakan fakultas dan program studi yang diminati oleh calon mahasiswa, dan dibutuhkan oleh masyarakat sebagai penggunanya.

2) Menyelenggarakan perkuliahan yang berbasis dan berorientasi pada bahasa, khususnya bahasa Inggris.

3) Menyelenggarakan perkuliahan berbasis teknologi informasi dan komunikasi.

4) Perguruan tinggi yang berbasis ISO terbaru.

5) Unit-unit kegiatan mahasiswa (UKM) harus diaktifkan dan ditingkatkan, sebagai salah satu wadah bagi mahasiswa untuk mengembangkan hobi, bakat dan minatnya.

\section{Price (Harga) Jasa Perguruan Tinggi}

Unsur pemasaran penting lainnya adalah harga yang merupakan sejumlah yang harus dibayarkan oleh konsumen untuk mendapatkan suatu produk.(Afidatun Hasanah, 2015) Pengertian harga menurut Deliyanti Oentoro adalah suatu nilai tukar yang bisa disamakan dengan uang atau barang lain untuk manfaat yang diperoleh dari suatu barang atau jasa bagi seseorang atau kelompok pada waktu tertentu dan tempat tertentu.(Sudaryono, 2016).

Menurut Saladin dan Oesman harga merupakan kekuatan nilai tukar barang dan jasa yang dapat meningkatkan volume penjualan dan keuntungan perusahaan. Harga adalah sejumlah uang sebagai alat tukar untuk memperoleh produk atau jasa. Harga juga dapat dikatakan sebagai penentu nilai suatu produk di benak konsumen.(Buchari Alma, 2008) Lebih lanjut dikatakan oleh Kotler tentang harga, bahwa harga merupakan satu-satunya elemen bauran pemasaran yang menghasilkan pendapatan. Elemen-elemen lainnya menimbulkan biaya. Harga juga merupakan salah satu elemen bauran pemasaran yang paling fleksibel. Harga dapat diubah dengan capat, tidak seperti ciri khas produk dan perjanjian distribusi. (Buchari Alma, 2008)

Harga dalam konteks jasa pendidikan merupakan seluruh biaya yang dikeluarkan oleh mahasiswa untuk mendapatkan jasa pendidikan yang ditawarkan oleh suatu perguruan tinggi. Dalam elemen harga PT dipertimbangkan mengenai penetapan harga (seperti SPP, biaya pembangunan, biaya laboratorium, dan biaya lainnya) pemberian beasiswa prosedur pembayaran, dan syarat cicilan. Harga akan sejalan dengan mutu dari suatu produk/jasa PT yang ditawarkan. Semakin tinggi mutu dari suatu produk/jasa PT, biasanya harga jasa pendidikan yang ditawarkan pun akan semakin tinggi. Misalnya, PT yang memiliki kualitas internasional (memenuhi standar mutu internasional) biasanya akan menetapkan harga di atas rata-rata, namun mahasiswa akan tetap bersedia membayar selama berada dalam batas keterjangkauan mereka untuk mendapatkan pendidikan bermutu tinggi tersebut. 


\section{Place (Lokasi/Tempat) Perguruan Tinggi}

Lokasi berarti berhubungan dengan tempat perusahaan jasa/produk harus bermarkas dan melakukan aktivitas kegiatannya. Dalam buku-buku pemasaran, place biasanya diterjemahkan sebagai saluran pemasaran. Menurut Kotler, saluran pemasaran adalah serangkaian organisasi yang saling tergantung dan tidak terlibat dalam proses untuk menjadikan produk atau jasa siap untuk digunakan atau dikonsumsikan.(Kotler, 2012) Lokasi yang strategis, nyaman dan mudah dijangkau akan menjadi daya tarik tersendiri bagi pelanggan.

(Hasanah, 2015) Pemilihan lokasi merupakan nilai investasi yang paling mahal,sebab lokasi bisa dikatakan menentukan ramai atau tidaknya pengunjung.(Rachmawati, 2011) Para pimpinan lembaga pendidikan sependapat bahwa lokasi letak lembaga yang mudah dicapai kendaraan umum, cukup berperan sebagai dasar pertimbangan bagi calon peserta didik dalam memilih lembaga pendidikan. Demikian pula para peserta didik menyatakan bahwa lokasi turut menentukan pilihan. Mereka menyenangi lokasi di kota dan yang mudah dicapai oleh kendaraan umum, atau terdapat fasilitas transportasi (bus umum) yang disediakan oleh pemerintah.(Imam Fauzin, 2017)

James dan Phillips mengategorikan unsur-unsur saluran distribusi jasa pendidikan menjadi tiga bagian, sebagaiberikut:

1) Penampilan (appearance) jasa pendidikan, yaitu seberapa efektif penampilan dan lokasi sekolah;

2) Pelanggan dan pengunjung (customers and their visitors) jasa pendidikan, dimana kultur jasa pendidikan yang berorientasi pada pelanggan jasa pendidikan harus memperhatikan pelanggan jasapendidikan;

3) Hubungan mula-mula dan aksesibilitas (first contact and accessibility) jasa pendidikan, yang berkaitan dengan cara individu berhubungan dengan sekolah dan kemudahan menjalin hubungan dengan sekolah.(David Wijaya, 2012)

Contoh dari posisi atau lokasi PT ideal adalah yang jauh dari kebisingan. Lokasi PT bisa saja dekat dengan perumahan, namun perlu bekerja sama dengan masyarakat sekitar untuk tetap menjaga suasana yang kondusif dan menyediakan sarana-sarana yang dibutuhkan oleh mahasiswa, misalnya tempat Kost, Kantin, Rental, tempat foto copy, Laundry, dan lain-lain. Yang tidak kalah pentingnya lagi, masyarakat sekitar sangat perlu diajak untuk bersama-sama mendukung mahasiswa untuk bisa kuliah dengan baik. Masyarakat juga harus bertanggungjawab untuk mengawasi mahasiswa dari tindakan-tindakan yang melanggar norma hukum, norma agama, norma sosial, dan norma-norma lainnya.

\section{Promotion (promosi) Jasa Perguruan Tinggi}

Unsur pemasaran lainnya adalah promosi yang merupakan kegiatan perusahaan dalam mengkomunikasikan penjualan produknya di pasaran dan berhubungan langsung dengan masyarakat. Menurut Huryati, sebagaimana yang dikutip oleh Firdayanti Abbas, promosi merupakan salah satu variabel marketing mix yang sangat penting untuk membuka pangsa pasar yang baru, atau memperluas jaringan pemasaran. Promosi merupakan aktivitas pemasaran yang berusaha untuk menyebarkan informasi, mempengaruhi/membujuk atau mengingatkan pasar sasaran (konsumen), atas perusahaan dan produknya agar bersedia menerima, membeli dan loyal pada produk yang ditawarkan oleh perusahaan yang bersangkutan. Promosi juga merupakan salah satu factor penentu keberhasilan program pemasaran. Sebaik apapun kualitasnya suatu produk, apabila konsumen belum pernah mendengarnya dan tidak yakin bahwa product ersebut akan berguna bagi mereka, maka mereka tidak akan pernah membelinya. Makanya tujuan dari promosi adalah untuk memberikan informasi dan meyakinkan konsumen akan manfaat produk tersebut. Promosi adalah suatu komunikasi informasi antar penjual dan pembeli yang bertujuan untuk mengubah sikap dan tingkah laku pembeli, yang tadinya tidak mengenal menjadi mengenal, sehingga menjadi pembeli dan tetap mengingat produk tersebut.

Dari penjelasan di atas dapat disimpulkan bahwa promosi merupakan suatu sarana 
untuk memberikan informasi dan meyakinkan konsumen akan manfaat suatu produk yang ditawarkan, sehingga pada akhirnya konsumen bisa mengenal dan tetap mengingat produk yang ditawarkan tersebut.

Kemudian dalam promosi jasa PT, kegiatan promosi dapat dilakukan melalui periklanan dimedia komunikasi massa misalnya: koran, majalah, televisi, papan reklame, dan gambar tempel. Kegiatan promosi lainnya juga bisa dilakukan dengan cara promosi penjualan (pameran dan invitasi), melakukan kontak langsung dengan calon mahasiswa, dan melakukan kegiatan hubungan dengan masyarakat. Adapun program yang sering diliput adalah ketika ada even-even tertentu, seperti ketika mendapatkan prestasi atau penghargaan dari pemerintah dan lain-lain. Demikian juga promosi juga bisa dilakukan melalui keterlibatan alumni-alumni yang senantiasa ikut mempromosikan kepada masyarakat. Hal ini sangat memberikan dampak yang sangat signifikan karena masyarakat lebih percaya dengan kesaksian orang- orang yang pernah terlibatdidalamnya.

Ada beberapa bentuk contoh promosi yang bisa dilakukan oleh Perguruan Tinggi, misalnya:

1) Melakukan kegiatan standarisasi, identitas dan citra perguruan tinggi, yaitu membuat standarisasi dan manual logo dan aplikasinya yang kemudian diterapkan dalam semua bentuk komunikasi dan format komunikasi PT yang bersangkutan. Membuat identitas PT yang unik dan menarik, misalnya dari logo dan slogan yang ditampilkan. Upaya ini dilakukan untuk membakukan brand name dan memantapkan branding.

2) Promosi dengan melakukan kegiatan Presentasi dan Kunjungan SMA/MA, Open House/Visit SMA ke kampus, Pelatihan Guru dan Siswa, Mengikuti Pameran Pendidikan di SMA/MA, Mengundang siswa mengikuti pelatihan di kampus, Iklan-iklan, dan sebagainya.

3) Public Relation, misalnya Even Universitas, Publisitas Media Massa, dll.

4) Layanan Placement Office , misalnya layanan student carrier, bursa kerja, dan sebagainya.

5) Mengaktifkan kerja Biro-biro yang ada di PT untuk aktif mengadakan kegiatan-kegiatan promosi dan kemahasiswaan. Misalnya membentuk forum-forum kerjasama, seminar, roadshow, membentuk ikatan orang tua mahasiswa, ikatan alumni, talk show ke berbagai media, event-eventkompetisi (olah raga, Debat Bahasa Inggris, Paduan Suara, Kesenian, $\mathrm{dsb})$

6) Semua unit layanan kampus wajib memberikan pelayanan kepada tamu/pelanggan yang bermutu, termasuk sopan dan ramah.

7) Mengundang secara khusus kepala SMA/MA yang siswanya berhasil diwisuda dengan IPK paling tertinggi atau wisudawan terbaik. Jika perlu seluruh akomodasi ditanggung oleh kampus (transportasi dan penginapan).

\section{People (orang/sumber daya manusia) Perguruan Tinggi.}

Sumber daya manusia adalah semua orang/pelaku yang terlibat dalam proses penyampaian jasa kepada konsumen serta mempengaruhi persepsi konsumen, misalnya para personel penyedia jasa, pelanggan, dan para pelanggan lain yang terkait dengan jasa tersebut. Hal ini sesuai dengan pendapat Zeithaml \& Bitner mengenai people, yaitu:

"All human actors who play a part in service delivery and thus influence the buyer's perceptions: namely, the firm's personnel, the customer, and other customers in the service environment".(Buchari Alma, 2008)

Dari pengertian di atas dapat dipahami bahwa orang (people) adalah semua pelaku yang memainkan peran dalam penyajian jasa sehingga dapat mempengaruhi persepsi pembeli. Elemen-elemen dari people adalah pegawai perusahaan, konsumen, dan konsumen lain dalam lingkungan jasa. Semua sikap dan tindakan karyawan dan penampilan karyawan mempunyai pengaruh terhadap persepsi konsumen atau keberhasilan penyampaian jasa.

Adapun people dalam konteks pendidikan ialah orang-orang yang terlibat dalam proses penyamaan jasa pendidikan seperti tata usaha, kepala sekolah, guru dan karyawan. Sumber 
daya pendidik dan kependidikan ini sangat penting, dan bahkan menjadi ujung tombak dalam proses pemberian layanan pendidikan, kepada para siswa selaku konsumen/pelangganjasa pendidikan.

Untuk mewujudkan Sumber Daya Manusia (guru) di lingkungan sekolah yangprofessional, diperlukan sistem rekrutmen yang profesional. Disamping itu, perlu untuk terus meningkatkan kompetensi guru dengan memberikan kesempatan dan beasiswa bagi guru untuk melanjutkan pendidikannya. Peningkatan melalui seminar dan pelatihan juga terus dilaksanakan sesuai dengan kebutuhan guru. Hal lain yang dipertimbangkan,guru juga harus ramah.

Selain guru yang berkualitas dan ramah, karyawan dan administrasi dan non administrasi juga diharapkan memiliki kehandalan dan keramahan dalam mengerjakan semua tugas. Oleh karena itu, perlu meningkatkan budaya ramah pada seluruh warga sekolah sehingga tercipta suasana belajar yang kondusif dengan harapan seluruh siswa termotivasi untuk meningkatkan pengetahuannya.

\section{Physical Evidence (bukti fisik) atau Sarana dan Prasarana PT}

Physical Evidence (bukti fisik), merupakan lingkungan fisik tempat jasa diciptakan, yang langsung berinteraksi dengan konsumennya. Dalam bauran pemasaran, terdapat dua macam physical evidence yaitu, pertama desain dan tata letak gedung seperti kelas, gedung sekolah, perpustakaan, lapangan olahraga dan lain- lain. Kedua, bukti pendukung yaitu nilai tambah yang bila berdiri sendiri tidak akan berperan apa-apa, seperti rapor, catatan siswa dan lain-lain.Sarana fisik merupakan komponen penting yang turut mempengaruhi keputusan konsumen untuk membeli dan menggunakan produk/jasa. Pada lembaga pendidikan, gedung atau bangunan dengan segala sarana dan fasilitas pendukungnya, dapat dikategorikan sebagai physical evidence. Pemenuhan bukti fisik sekolah, akan memberi dorongan kepada siswa (dan orang tua/wali), untuk memilih lembaga pendidikan tersebut, sebagai pilihan investasi masa depannya. Sebab ketersediaan fasilitas penunjang merupakan indikasi awal, bahwa lembaga pendidikan tersebut, memiliki mutu dan kualitas pendidikan yang baik.

Jadi pada prakteknya, dalam menyampaikan jasa pendidikan yang tidak berwujud (intangible) kepada mahasiswa, perguruan tinggi harus selalu melibatkan adanya produkproduk pendukung yang berwujud (tangible). Misalnya menyediakan buku-buku diperpustakaan yang selalu up to date, memberikan kemudahan bagi mahasiswa untuk mencari buku-buku yang mereka butuhkan di perpustakaan, dan menyediakan tempat yang kondusif, baik untuk membaca maupun untuk diskusi.(Buchori Alma, 2008) Dengan demikian dapat dipahami bahwa bukti fisik memainkan peran yang sangat penting dan seringkali merefeksikan kualitas dari pelayanan yang akan diberikan oleh perguruan tinggi.

Ada beberapa contoh bukti fisik yang harus dimiliki oleh sebuah perguruan tinggi, yaitu: fasilitas kampung, perpustakaan, internet, laboratorium dan studio, pojok bursa, poliklinik, ATM, placement office, sarana ibadah, sarana parkir, sarana olahraga, auditorium, ruang teater, ruang seminar, tempat makan/kantin, kemahasiswaan.

\section{Process (proses) atau Manajemen Layanan PT}

Menurut Zeithmal \& Bitner, proses didefenisikan sebagai: The actual procedures, mechanisms, and flow of activities by which the service is delivered-the service delivery and operating system. Maksudnya, proses merupakan suatu prosedur, mekanisme, dan rangkaian kegiatan untuk menyampaikan jasa dari produsen kepada konsumen.(Buchori Alma, 2008) Jadi proses merupakan salah satu faktor yang berpengaruh dalam pemasaran, khususnya dalam bentuk jasa. Hal ini disebabkan karena pelanggan/konsumen jasa, dalam proses pemenuhannya 
juga terlibat secara aktif sebagai bagian dari jasa itu sendiri. Menurut Imam Machali, dikutip oleh Afidatun Khasanah, bahwa proses diartikan sebagai prosedur dalam rangkaian aktivitas untuk menyampaikan jasa dari produsen ke konsumen. Dalam konteks jasa pendidikan, proses adalah prosedur pendidikan yang mendukung terselenggaranya proses kegiatan belajar mengajar guna terbentuknya produk/lulusan yang diinginkan.(Imam Machali, 2016).

Dengan tercapainya kepuasan pelanggan PT, diharapkan tingkat loyalitas mereka terhadap perguruan tinggi akan meningkat. Loyalitas mahasiswa dapat diukur melalui frekuensi mereka mengikuti perkuliahan rutin, memberikan sarana yang membangun kepada perguruan tinggi, menyarankan orang lain untuk kuliah di perguruan tinggi tersebut, tidak pindah ke perguruan tinggi lain, kebal terhadap daya tarik perguruan tinggi lain, dan menjaga hubungan harmonis dengan perguruan tinggi.

Ada beberapa proses terbaik yang harus dilakukan oleh perguruan tinggi, yaitu: kebijakan berbasis mutu, berorientasi kepada kepuasan pelanggan, efisiensi, friendly campus, business and commerce, dll.

7P dalam strategi pemasaran jasa perguruan tinggi di atas semuanya saling berhubungan dan mempengaruhi, sehingga semuanya penting sebagai satu kesatuan strategi, yaitu strategi acuan/bauran. Sedangkan strategi bauran pemasaran ini merupakan bagian dari strategi pemasaran, dan berfungsi sebagai pedoman dalam menggunakan unsur-unsur atau variabel- variabel pemasaran yang dapat dikendalikan pimpinan organisasi, untuk mencapai tujuan organisasi dalam bidang pemasaran.

\section{KESIMPULAN DAN SARAN}

Strategi adalah suatu rencana cermat mengenai kegiatan untuk mencapai sasaran khusus. Sedangkan pemasaran adalah suatu proses sosial manajemen yang bertanggung jawab untuk mengenali, mengantisipasi dan memuaskan keinginan atau kebutuhan pembeli demi meraih laba. Strategi pemasaran adalah cara atau langkah-langkah taktis yang digunakan untuk memahami kebutuhan dan memprediksikan gejala permintaan konsumen.

Dalam penerapan strategi pemasaran jasa pendidikan dapat diklasifikasi menjadi dua tahapan, yaitu perencanaan dan pelaksanaan. Pada tahapan perencanaan melakukan tahapan-tahapan sebagai berikut, yaitu : identifikasi pasar, segmentasi pasar dan positioning, diferensiasi produk, komunikasi pemasaran, dan pelayanan madrasah. Sedangkan pelaksanaan pemasaran itu bisa menggunakan strategi bauran pemasaran (marketing mix) yang didalamnya ada empat atau tujuh aspek, yaitu: produk, harga, lokasi, promosi, sumber daya manusia, bukti fisik, dan proses.

\section{DAFTAR RUJUKAN}

Anonim. 2005. Kamus Besar Bahasa Indonesia (KBBI). Jakarta: Balai Pustaka. Afidatun Khasanah. 2105. Pemasaran Jasa Pendidikan Sebagai Strategi Peningkatan Mutu di SD Alam Baturraden. JurnalEl-Tarbawi, 8(2),

Ali Hasan. 2010. Marketing Bank Syari'ah . Bogor: Ghalia Indonesia

David Wijaya. 2012. Pemasaran Jasa Pendidikan. Jakarta: Salemba Empat.

Fandy Tjiptono. 2014. PemasaranJasa. Yogyakarta: Penerbit Andi.

Husein Umar.2010. Desain Penelitian Manajemen Strategik. Jakarta: PT. Raja Grafindo Persada.

Sudaryono. 2016. Manajemen Pemasaran; Teori dan Implementasi (Yogyakarta: Penerbit Andi.

Yoyon Bahtiar Irianto dan Eka Prihatin. 2011 Pemasaran Pendidikan; Manajemen Pendidikan. Bandung: Alfabeta. 